\title{
Revising the Gent Formation: a new lithostratigraphy for Quaternary wind-dominated sand deposits in Belgium
}

\author{
Koen BEERTEN ${ }^{1 *}$, VANessa M.A. HEYVAERT ${ }^{2}$, Dimitri A.G. VANDENBERGHE ${ }^{3}$, JASPER VAN NIEULAND ${ }^{3} \&$ FrIEDA BOGEMANS $^{4}$ \\ ${ }^{1}$ Engineered and Geosystems Analysis, SCK•CEN, 2400 Mol,Belgium; kbeerten@sckcen.be. \\ ${ }^{2}$ Royal Belgian Institute of Natural Sciences, Geological Survey of Belgium, 1000 Brussels, Belgium \& Department of Geology, Ghent \\ University, 9000 Ghent, Belgium; vanessa.heyvaert@naturalsciences.be. \\ ${ }^{3}$ Laboratory of Mineralogy and Petrology (Luminescence Research Group), Department of Geology, Ghent University, 9000 Ghent, \\ Belgium; dimitri.vandenberghe@ugent.be. \\ ${ }^{4}$ Royal Belgian Institute of Natural Sciences, Research Unit Quaternary Environment and Humans, 1000 Brussels, Belgium; \\ fbogemans@naturalsciences.be. \\ "corresponding author
}

ABSTRACT. In Belgian lithostratigraphy, the Gent Formation was previously introduced to encompass all Quaternary sandy aeolian sediments. It has been difficult to apply, however, as it was incomplete, regionally biased, and not based on sediment properties alone. To solve this problem the Gent Formation is revised both in terms of definition and subdivision. Morphological and chronological criteria were omitted to allow ranking strata on the basis of visible lithological properties. The Belgian sand belt is newly introduced to designate the area where these sediments were deposited. The Gent Formation is subdivided into five members based on distinct lithological properties, and as a consequence reflecting different palaeoenvironmental conditions during deposition. Whenever feasible, each member is put in a chronostratigraphical and geomorphical context. The new subdivision is discussed and compared with earlier Belgian lithostratigraphical frameworks, as well as to the most recent one for comparable deposits in the Netherlands.

KEYWORDS: aeolian, fine, homogeneous, stratified, quartz-rich, silty, palaeosoil, periglacial, Holocene.

\section{Introduction}

The Gent Formation was introduced by Paepe \& Vanhoorne (1976) to include "all coversands deposited during the Weichselian”. Gullentops et al. (2001) extended the chronostratigraphical position of the Gent Formation to all sandy aeolian coversand deposits dating from the Middle and Late Pleistocene (Tables $1 \& 2$ ) and subdivided the formation in three members: the Dilsen Member (pre-Weichselian), the Sint-Lenaarts Member and the Wildert Member (both Weichselian). The Dilsen Member was initially introduced by Paulissen (1973) to include the coversand deposits in which an interglacial (Eemian) soil had developed. The Sint-Lenaarts Member was originally defined by De Ploey (1961) as reworked aeolian sand, with silt and peat layers, occurring underneath the Wildert Member. The latter included all coversand deposits that covered the pre-existing landscape as a blanket.
In the scheme proposed by Gullentops et al. (2001), aeolian sands that constitute a dune landform where grouped into the Hechtel Formation. This formation included Late Glacial dune sands covering the Usselo Soil (Gullentops, 1957), as well as drift sands originating from aeolian reworking of older dune sands and Podzols during the Holocene (grouped in the Kalmthout Member; De Ploey, 1961).

While the lithostratigraphical framework by Gullentops et al. (2001) describes the local and regional geological history of young Quaternary aeolian sands, it has been difficult to apply in the field. Many of the subdivisions in formations and members are based on morphological and chronostratigraphical criteria, other than the visible lithological properties of the sediments under consideration.

\begin{tabular}{|c|c|c|c|c|c|c|}
\hline \multirow{2}{*}{ (Sub)series } & \multirow{2}{*}{ Marine } & \multicolumn{3}{|c|}{ Fluvial } & \multirow{2}{*}{\multicolumn{2}{|c|}{ Aeolian }} \\
\hline & & Schelde (Scheldt) & \multicolumn{2}{|c|}{ Maas (Meuse) } & & \\
\hline Holocene & Vlaanderen Fm. & Arenberg Fm.** & \multicolumn{2}{|c|}{ Stokkem Fm.** } & \multicolumn{2}{|c|}{ Hechtel Fm. } \\
\hline \multirow{2}{*}{ Late Pleistocene } & & Eeklo Fm. & \multirow{2}{*}{\multicolumn{2}{|c|}{ Lanklaar Fm. }} & \multirow{5}{*}{ Gent Fm. } & Gembloux Fm.*** \\
\hline & Oostende Fm. & Oostwinkel Fm. & & & & \\
\hline \multirow{3}{*}{ Middle Pleistocene } & & Adegem Fm. & & & & \\
\hline & Herzeele Fm. & Melle Fm. & \multicolumn{2}{|c|}{ Lanaken Fm. } & & \\
\hline & & Meulebeke Fm. & \multicolumn{2}{|c|}{ Zutendaal Fm. } & & \\
\hline \multirow{2}{*}{ Early Pleistocene } & \multirow{3}{*}{ Kempen Group } & Kruishoutem Fm. & \multirow{2}{*}{ Sterksel Fm. } & \multirow{2}{*}{ Lixhe Fm. } & & \\
\hline & & \multirow{2}{*}{ Rozebeke Fm. } & & & & \\
\hline Pliocene* & & & \multicolumn{2}{|c|}{ Simpelveld Fm. } & & \\
\hline
\end{tabular}

* In Gullentops et al. (2001), the Pliocene includes the Tiglian pollen stage.

** The Arenberg and Stokkem Fms. continue into the latest part of the Late Pleistocene (Late Glacial).

*** The Romont Group is subdivided into the Gembloux and Veldwezelt Fms., according to Haesaerts et al. (2011).

Table 1. Quaternary lithostratigraphy of marine, fluvial and aeolian deposits of Belgium, as defined in Gullentops et al. (2001). 


\begin{tabular}{|c|c|c|c|c|c|}
\hline \multicolumn{2}{|c|}{ This study } & \multicolumn{2}{|c|}{ Gullentops et al., 2001} & \multicolumn{2}{|r|}{ TNO, 2013} \\
\hline Formation & Member & Formation & Member & Formation & Member \\
\hline \multirow{6}{*}{ Gent } & De Panne & Vlaanderen $^{1}$ & De Panne ${ }^{3}$ & Naaldwijk $^{6}$ & Schoorl $^{6}$ \\
\hline & Achterbos & \multirow{2}{*}{ Hechtel $^{1}$} & Kalm thout $^{4}$ & \multirow{5}{*}{ Boxtel $^{7}$} & Kootwijk $^{7}$ \\
\hline & \multirow{2}{*}{ Opgrimbie } & & & & Wierden and Delwijnen ${ }^{7}\left(\right.$ Younger Coversand $\left.^{8}\right)$ \\
\hline & & Gent $^{2}$ & Wildert ${ }^{4}$ & & Undifferentiated $^{7}\left(\right.$ Older Coversand $\left.^{8}\right)$ \\
\hline & Tisselt & Gent $^{2}$ & Sint-Lenaarts ${ }^{4}$ & & Undifferentiated $^{7}$ \\
\hline & Dilsen & Gent $^{2}$ & Dilsen $^{5}$ & & Undifferentiated $^{7}$ \\
\hline
\end{tabular}

${ }^{1}$ Gullentops (1957); ${ }^{2}$ Paepe \& Vanhoorne (1976); ${ }^{3}$ Depuydt (1972); ${ }^{4}$ De Ploey (1961); ${ }^{5}$ Paulissen $(1973) ;{ }^{6}$ Weerts (2003); ${ }^{7}$ Schokker et al. $(2005)$;

${ }^{8}$ Van der Hammen (1951) and Van der Hammen \& Wijmstra (1971).

Table 2. Correlation between the latest version of the Dutch lithostratigraphy (TNO, 2013), the scheme proposed by Gullentops et al. (2001), and the lithostratigraphy proposed in this study.

Furthermore, this framework does not include the aeolian sand deposits present in the coastal area, nor those deposited in the transitional area between the sand belt and loess area.

Building on the earlier scheme, and based on recent research and experiences with its actual possibilities and limitations for mapping, this paper presents a new lithostratigraphical framework for the young Quaternary wind-dominated sand deposits in Belgium. The Gent Formation is revised to include all types of fine sandy deposits present in the coastal area, the "coversand" area and the so-called transitional area, that have a more or less homogeneous appearance. The depositional area is designated as the "Belgian sand belt" (Fig. 1). The use of terms such as "coversand", "dune sand" and "drift sand" is abandoned, as they refer to geomorphic and genetic processes (with connotations as to age). The present classification uses macroscopically visible lithological properties of the sediments to distinguish and rank them, including post-depositional features such as soil horizons and cryogenic structures. Within the Gent Formation, five members are recognised. The scheme is compared with the most recent Quaternary lithostratigraphy of the Netherlands, although it was beyond the scope of this particular exercise to establish firm correlations.

\section{General characteristics of the Gent Formation, and its relation to other lithostratigraphical units}

Defining formal units requires strict rules. Here we briefly list the requirements to define them and add some explanations (International Commission on Stratigraphy, 2015). A lithostratigraphical unit is a body of rocks that is defined and recognized on the basis of its lithological properties or combination of lithological properties and stratigraphical relations. This implies that upper and lower boundaries are important elements to define a lithostratigraphical unit, and that the nature of these boundaries may be included as diagnostic criteria (e.g., a hiatus characterised by erosional or pedogenic processes). The formation is the primary formal unit of lithostratigraphical classification. A formation is the only formal lithostratigraphical unit into which the stratigraphical column should be divided solely on the basis of lithology. The contrast in lithology between formations required to justify their establishment varies with the complexity of the regional geology. It also varies with the detail needed for geological mapping and to work out the regional geological history. A formation is considered justifiable if it can be delineated at
Figure 1. Location of the Belgian sand belt, including the coversand area and the transitional zone to the loess area. Also indicated are the locations of the stratotype(s) for the formation and the five individual members.

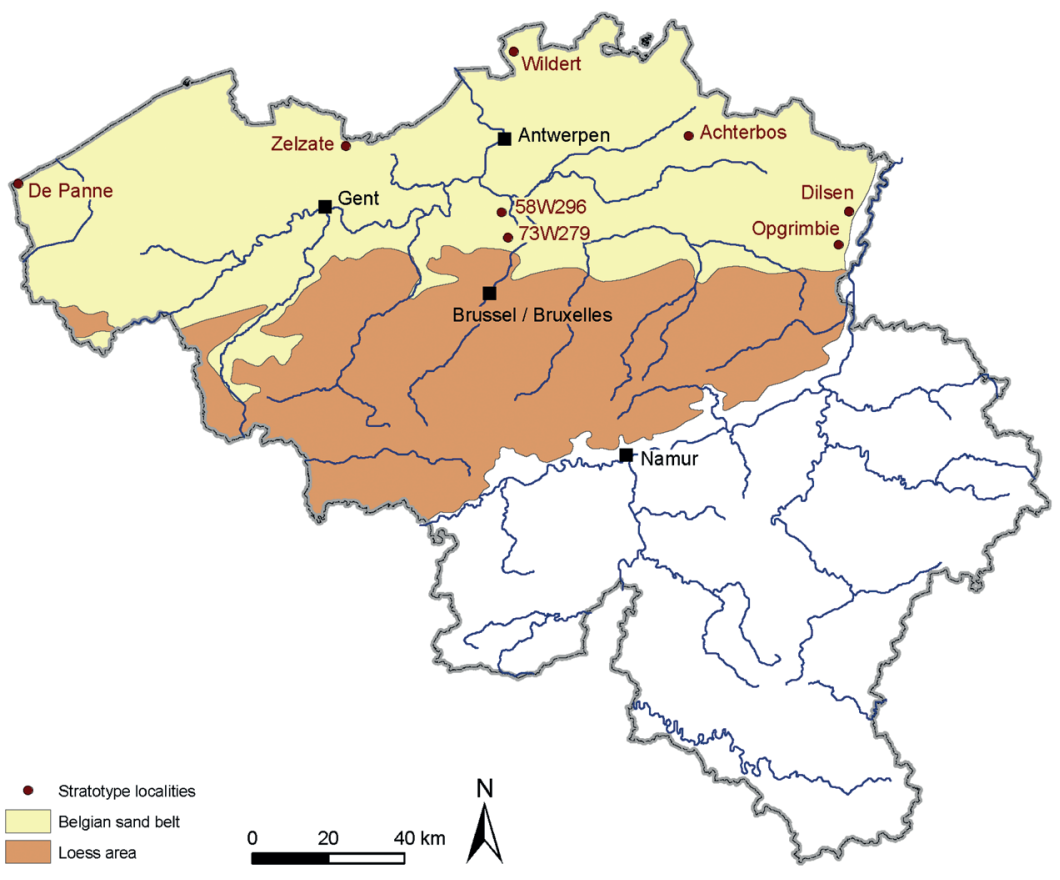



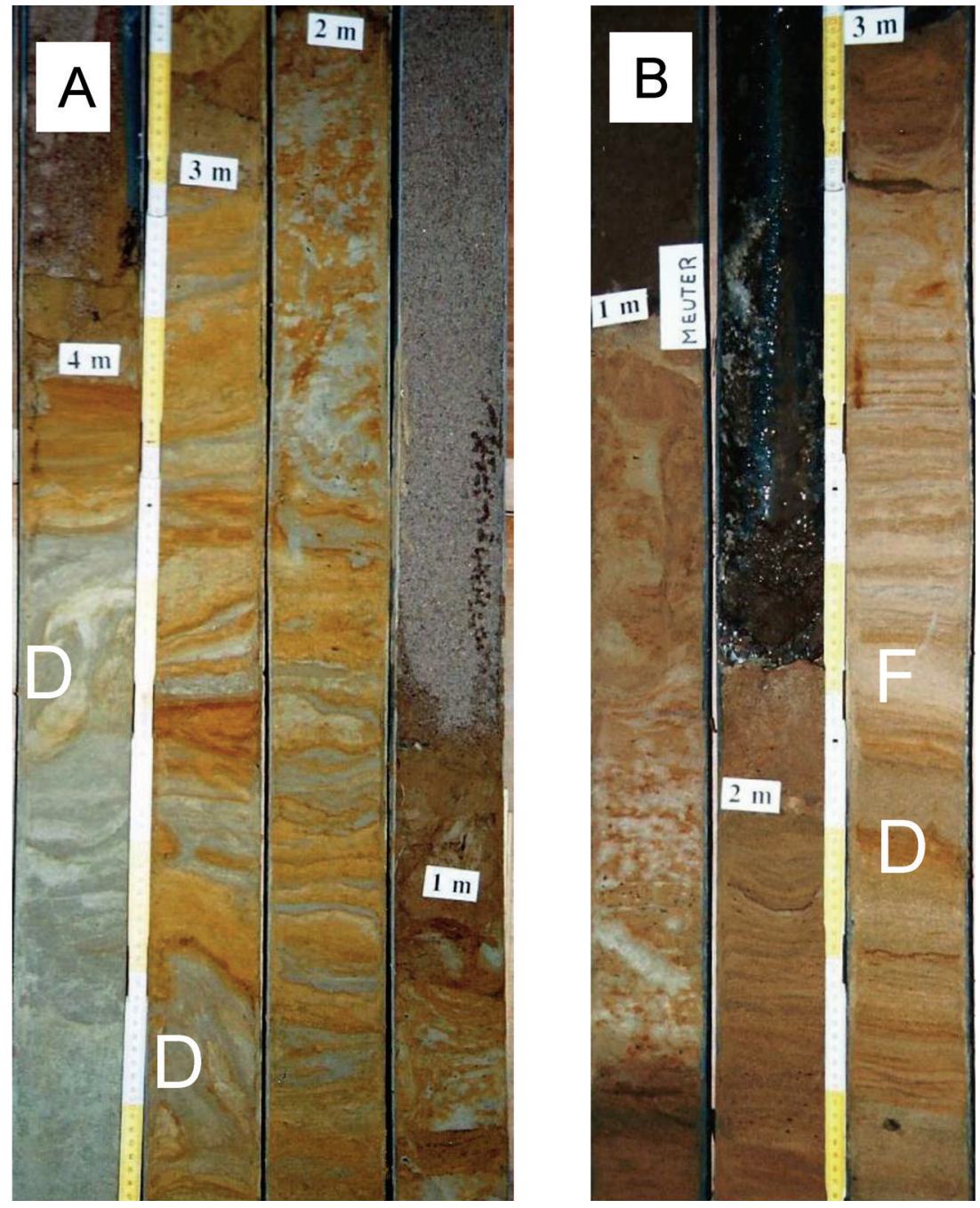

Figure 2. A: The Tisselt Member within the Belgian sand belt (core 58E296). The yellow coloured sediments are sandy, the grey ones are silty. Periglacial deformation structures are visible on several levels. The bounding planes of the beds and laminae are clearly delineated B: The Tisselt Member in the southern part of the Belgian sand belt, the former transitional part (core 73W279), containing a higher silt percentage. The silt layers are thicker (pale coloured layers on the photograph) and the sand deposits have a significant silt content. Note the small frost crack (F) and the small deformation structures (D) in several levels (Photographs by F. Bogemans).

the scale of geological mapping practiced in the region. The member is the next lithostratigraphical unit in rank. Members are defined when they possess different lithological properties than adjacent parts of the formation. A formation does not need to be divided into members, unless it serves a useful purpose. In the present case of the Gent Formation, members are defined to help understand the Late Quaternary history of the region, based on detailed lithological differences between them, and their stratigraphical relationships.

The Gent Formation essentially consists of well-sorted relatively pure fine sands, with increasing amounts of silt in the transitional zone towards the loess area (Table 3). The median grain size is between $125-250 \mu \mathrm{m}$, and this fraction usually represents at least half of the bulk sediment mass. The mineralogy is dominated by quartz, the sediments are poor in carbonates and may contain various amounts of iron, depending on the degree of weathering and drainage class of the soil that may have developed in it. If present, organic material is part of the matrix or coated around grains; occasionally thin organic-rich layers can be observed. Another feature of the Gent Formation is the dull appearance of the grain surface texture, resulting from grain-to-grain impact during aeolian transport. Various types of stratification may be encountered, such as oblique and horizontal, but the sediments can also be massively bedded. Sandy and silty layers may alternate in the formation. Within the formation, many palaeosols can be found, such as the Rocourt Soil and the Usselo Soil (see Gullentops et al., 2001; Table 3). It has also been affected by Holocene soil development. Periglacial deformation phenomena are present at various levels, as well as thin gravelly horizons that can be interpreted as desert pavements. The thickness of the formation is typically several metres; locally it can be very thin (in the order of decimetres) or reach up to 10 metres. The upper boundary usually coincides with the surface, except in alluvial plains where the formation may be covered by younger fluvial deposits (e.g., Arenberg Formation; Table 1). The lower boundary is commonly nonerosional with respect to underlying lithostratigraphical units and sometimes quite sharp. Sediments from the Gent Formation can be found overlying coarse fluvial gravel and sand from the Scheldt, Rhine and Meuse rivers, and Quaternary, Neogene and Paleogene marine and estuarine sands and clays. The stratotype for the Gent Formation is the section described by Paepe \& Vanhoorne (1967) that became exposed during road tunnel constructions in Zelzate (Lambert coordinates: $\left.\mathrm{x}=110314, \mathrm{y}=209349 ; 51^{\circ} 12^{\prime} \mathrm{N}, 3^{\circ} 48^{\prime} \mathrm{E}\right)$.

In the Netherlands, equivalent sediments belong to the Boxtel Formation (Schokker et al., 2005, 2007). However, the Gent Formation cannot simply be replaced by the Boxtel Formation because some members of the former are ranked in other formations in the Belgian lithostratigraphy. For example, The Boxtel Formation includes loess deposits (Schimmert Member) which are included in the Romont Group in Belgium (Haesaerts et al., 2011). Besides, the Boxtel Formation encloses not only aeolian deposits but also deposits generated by small rivers (Schokker et al., 2005, 2007), which in Belgium are also classified in other formations (e.g., Arenberg Formation; Table 1).

\section{Subdivision of the Gent Formation}

\subsection{Dilsen Member}

The Dilsen Member consists of yellow horizontally laminated slightly silty sands (Table 3). Typically, an interglacial soil with a reddish-brown $\mathrm{Bt}$ horizon can be observed in these sands, which is thought to be the equivalent of the Eemian Rocourt pedocomplex in the loess sections (Haesaerts et al., 2011). 


\begin{tabular}{|c|c|c|c|c|c|c|c|}
\hline Member & $\begin{array}{c}\text { Dominant } \\
\text { lithology }\end{array}$ & $\begin{array}{c}\text { Minor } \\
\text { lithology }\end{array}$ & Appearance & Stratification & $\begin{array}{c}\text { Deformation } \\
\text { phenomena }\end{array}$ & Soils & Colour \\
\hline De Panne & Sand & $\begin{array}{l}\text { Shell } \\
\text { remains }\end{array}$ & Homogeneous & Cross-stratification & Bioturbations & Incipient soils & Yellow-grey to grey \\
\hline Achterbos & Sand & Silt & Homogeneous & $\begin{array}{c}\text { Massive, horizontal } \\
\text { and cross- } \\
\text { stratification }\end{array}$ & Bioturbations & $\begin{array}{l}\text { Incipient soils; weakly } \\
\text { developed Podzols }\end{array}$ & Greyish-yellow \\
\hline Opgrimbie & Sand & $\begin{array}{l}\text { Silt, } \\
\text { clay, } \\
\text { peat, } \\
\text { gravel }\end{array}$ & Homogeneous & $\begin{array}{c}\text { Massive, horizontal } \\
\text { and cross- } \\
\text { stratification }\end{array}$ & $\begin{array}{c}\text { Bioturbations, } \\
\text { cryoturbations, ice- } \\
\text { wedge casts and frost } \\
\text { cracks }\end{array}$ & $\begin{array}{c}\text { Well-developed } \\
\text { Podzols; bleached } \\
\text { horizons (Usselo soil) }\end{array}$ & $\begin{array}{c}\text { White to grey, yellow } \\
\text { and brown }\end{array}$ \\
\hline Tisselt & $\begin{array}{l}\text { Sand and } \\
\text { silt }\end{array}$ & Clay & $\begin{array}{l}\text { Alternated } \\
\text { bedded }\end{array}$ & $\begin{array}{l}\text { Massive, horizontal } \\
\text { and small ripples }\end{array}$ & $\begin{array}{l}\text { Cryoturbations, ice- } \\
\text { wedge casts and frost } \\
\text { cracks }\end{array}$ & Usually absent & $\begin{array}{l}\text { Yellow to grey, } \\
\text { sometimes olive-grey }\end{array}$ \\
\hline Dilsen & Silty sand & Clay & Homogeneous & Massive & Bioturbations & $\begin{array}{c}\text { Bt horizon } \\
\text { (Rocourt soil) }\end{array}$ & Yellow \\
\hline
\end{tabular}

Table 3. Diagnostic criteria to identify individual members within the Gent Formation.

The member is most frequently found overlying the EisdenLanklaar Meuse terrace of Saalian age (Gullentops et al., 2001) and is covered by younger fine sandy deposits (Opgrimbie Member or Achterbos Member, see sections 3.3 \& 3.4).

In the Belgian sand belt, the Dilsen Member is only preserved in places where it was protected from subsequent erosion, e.g. through burial by younger deposits. The original stratotype is located in Dilsen-Vossenberg $\left(51^{\circ} 02^{\prime} 22^{\prime \prime} \mathrm{N}\right.$, $5^{\circ} 41^{\prime} 18$ ”'E; Fig. 1), but it is difficult to access (Paulissen, 1973). In general, the deposits are 1-2 metres thick, but occasionally can reach thicknesses of up to 10 metres.

Paulissen (1973) informally introduced the Dilsen Formation as a coversand deposited during the Saalian glacial stage (probably MIS6; Martinson et al., 1987), based on morphological and pedostratigraphical criteria (Table 4). The unit was later formally ranked as a member within the Gent Formation (Gullentops et al., 2001). The Dilsen Member is not formally identified in the lithostratigraphical framework of the Netherlands. Equivalent sediments belong to the Boxtel Formation in the Netherlands (Schokker et al., 2005), and formerly were part of the disused Eindhoven Formation (Doppert et al., 1975).

\subsection{Tisselt Member}

The Tisselt Member consists of yellow to grey interlayered deposits of silty and sandy beds or laminae of which the bounding surfaces are sharp or gradual (Table 3). The texture is related to the depositional areas; sand prevails in the northern part of the Belgian sand belt (Fig. 2A) whereas in the southern transitional area silty sand to sandy silt dominates
(Fig. 2B). Massive bedding, horizontal bedding and small ripple bedding is observed. Frost cracks and periglacial deformation structures are common on several levels.

If present, the Tisselt Member overlies older Quaternary or pre-Quaternary deposits, and it is covered by or laterally equivalent to the Opgrimbie Member (see Section 3.3). Two stratotypes are defined for this member as the textural composition of this unit differs for different depositional areas. The stratotype for the northern part of the sand belt is core 58E296 (Lambert coordinates: $\mathrm{x}=151159$, $\mathrm{y}=191869$; $\mathrm{z}$ $=7.91 \mathrm{~m}$ TAW (second general levelling at Ostend seaport)). The stratotype for the transitional area is core $73 \mathrm{~W} 279$ (Lambert coordinates: $\mathrm{x}=152840, \mathrm{y}=185257 ; \mathrm{z}=13.5 \mathrm{~m}$ TAW) (Fig. 1). The Tisselt Member may be up to a few metres thick.

There is no absolute age available for this member. Based on stratigraphical correlations, the member has been deposited during the Weichselian, most probably during MIS2 and MIS3 as the partly laterally equivalent Opgrimbie Member was deposited mainly during MIS2 (see Section 3.3; Table 4). Bogemans (1988, 1993) informally introduced the Tisselt Member. In its present definition, it includes the deposits of the former Sint-Lenaarts Member as described in Gullentops et al. (2001). In older literature, deposits of the Tisselt Member were incorporated in the Blaak Member (Vandenberghe, 1985) and the unnamed 'laminated sands and silts' member (Vandenberghe \& Gullentops, 1977). In the current Dutch lithostratigraphy, equivalent sediments are included in the Boxtel Formation, but it is difficult to formally link them to a specific member.

\begin{tabular}{|c|c|c|c|}
\hline Member & $\begin{array}{c}\text { W. European } \\
\text { chronostratigraphy }\end{array}$ & Marine isotope stage $^{2}$ & $\begin{array}{c}\text { Approximate boundaries } \\
\text { (ka BP) }\end{array}$ \\
\hline De Panne & Holocene & MIS1 & $0-12$ \\
\hline Achterbos & Holocene & MIS1 & $0-12$ \\
\hline \multirow{2}{*}{ Opgrimbie } & $\begin{array}{c}\text { (Holocene) } \\
\text { Late Glacial } \\
\text { Late Pleniglacial }\end{array}$ & MIS1) & MIS2 \\
\hline Tisselt & Late Pleniglacial & MIS2 & $12-15$ \\
& Middle Pleniglacial & MIS2 & $15-25$ \\
\hline Dilsen & Saalian & MIS3 & $15-25(?)$ \\
& \multicolumn{2}{|c|}{ MIS6 } & $25(?)$ \\
\hline
\end{tabular}

Table 4. Chronostratigraphy of the Gent Formation.
${ }^{1}$ Vandenberghe, 1985; Busschers et al., 2007

${ }^{2}$ Martinson et al., 1987 

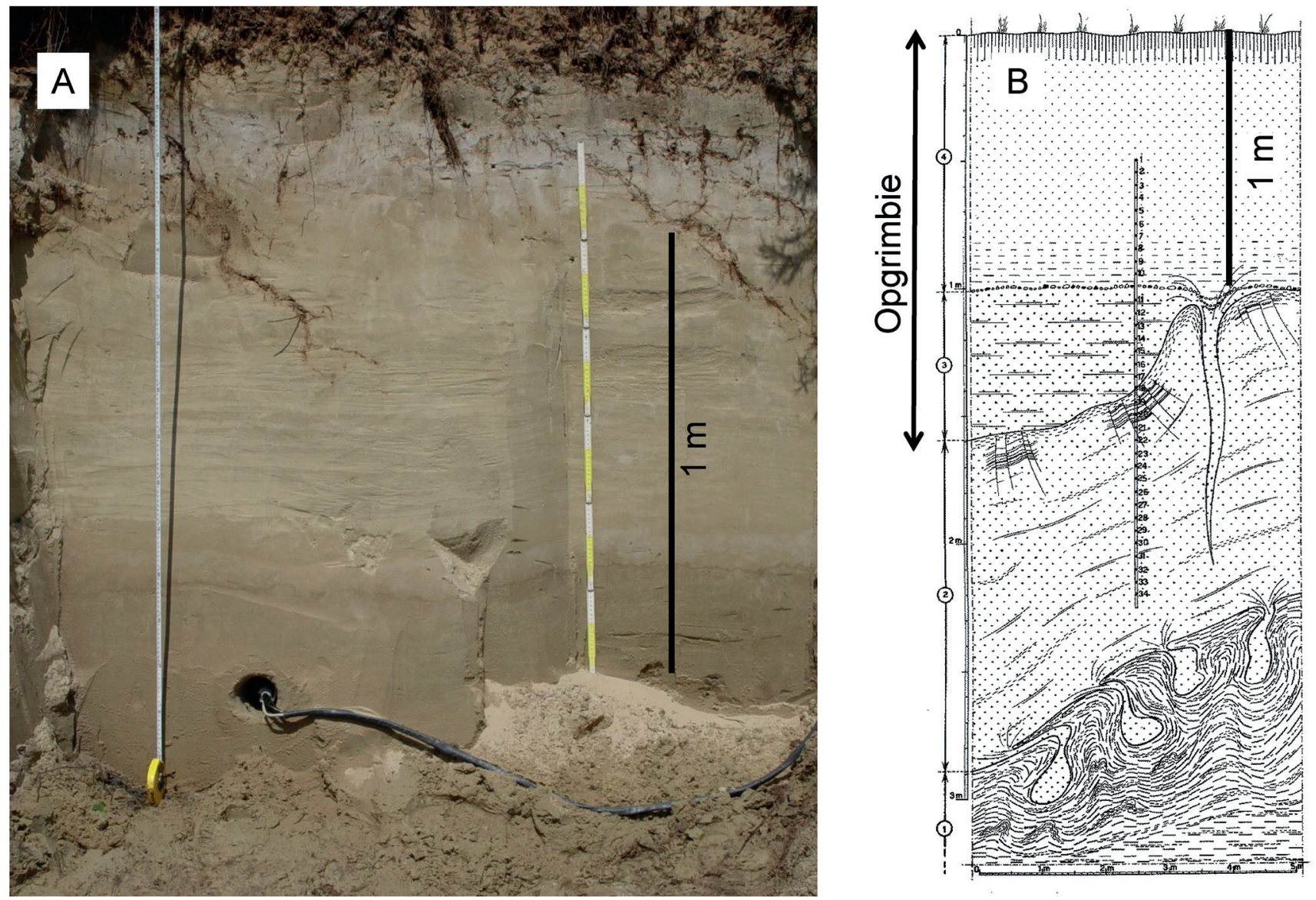

Figure 3. A: The Opgrimbie Member at one of its type localities (Opgrimbie) showing massive bedding. At other locations, the sediments may be laminated and/or show cross-bedding (Photograph D. Vandenberghe). B: The Opgrimbie Member at another type locality near Wildert, with ice-wedge casts and gravel pavement (drawing from De Ploey, 1961).

\subsection{Opgrimbie Member}

The Opgrimbie Member consists of homogeneous sand and silty sand. The colour is pure and bright white, to grey, yellow and brown, and is dependent on local hydro- and/ or pedological processes (Table 3). Massive stratification is dominant; horizontal or oblique stratification may be present (Fig. 3A). Cryoturbations, frost cracks and frost wedges can be present in the sediments, as well as thin (usually one pebblethick) gravel horizons (Fig. 3B). Intercalated soil horizons, organic-rich beds and clay-enriched lamellae are frequently observed. The intercalated soils can be weak, well-developed or degraded, and their appearance depends on the parent material in which they developed (Fig. 4). A cultural layer is common at the top.

The Opgrimbie Member covers the Tisselt Member (if the latter is present) or can be laterally equivalent to it. In sequences, it can usually be distinguished from the overlying Achterbos Member (if present), essentially on account of colour and/or an intercalated organic-rich (soil) horizon or a cultural layer and the packing. Deposits from the Opgrimbie Member can be found throughout the Belgian sand belt area. They cover almost the entire pre-existing topography as a blanket, locally forming dunes. The deposits may be very thin but can reach thicknesses of up to several metres in preexisting depressions and dune areas.

Two stratotypes are defined for this member (Fig. 1). The first stratotype is the dune complex at Opgrimbie (N50 $57^{\prime} 13$ ', $\left.\mathrm{E} 5^{\circ} 38^{\prime} 52^{\prime \prime}\right)$, where laminated and homogeneous wind-blown sands can be observed, together with intercalated soil horizons (bleached horizons; Fig. 3A; Paulissen \& Munaut, 1969). The second stratotype is located in Essen (Wildert; N51 $25^{\prime}$, E4 ${ }^{\circ} 26^{\prime}$ ) where the pebble horizon and periglacial deformation phenomena are described in abandoned clay excavation pits (Fig. 3B; De Ploey, 1961; Gullentops et al., 2001).
Abundant absolute age control is available for this member. Optically stimulated luminescence dating systematically indicates an age range between ca. $23 \mathrm{ka}$ and ca. $11 \mathrm{ka}$, covering the late Pleniglacial and Late Glacial (MIS2; see e.g. Bogemans \& Vandenberghe, 2011; Buylaert et al., 2009; Derese et al. 2009; 2010a; 2010b; 2012; Vandenberghe et al., 2009; Van Nieuland et al. 2013a). Occasionally, sand deposits of the Opgrimbie Member have also been dated to the Holocene (see, e.g., Van Nieuland et al., 2013b).

The Opgrimbie Member is newly introduced to comprise the cover and dune sands previously defined as the Wildert Member and the Hechtel Formation (but excluding the Kalmthout Member) by Gullentops et al. (2001). The new name is introduced to avoid confusion with and the morphological connotation of the old terminology. It also includes the river dunes described in Gullentops et al. (1981). In the Netherlands, equivalent sediments belong to the Boxtel Formation. More in particular, the Opgrimbie Member is at least partly the equivalent of the Wierden Member and the Delwijnen Member (TNO, 2013). However, it also comprises undifferentiated sands from the Boxtel Formation. In previous lithostratigraphical schemes for the Netherlands, the sediments from the Opgrimbie Member were ranked as Younger Coversand (YC) and Older Coversand (OC), locally separated by a loamy bed (Van der Hammen, 1951; Van der Hammen and Wijmstra, 1971). The Younger Coversand was subdivided into YC1 and YC2 by the Usselo soil, where YC2 morphologically stands out as low amplitude dunes. The Older Coversands were also subdivided into $\mathrm{OC} 1$ and $\mathrm{OC} 2$, and separated by a gravelly unit called the Beuningen Gravel, interpreted as a desert pavement. Periglacial deformation phenomena were only observed in the lowermost OC1. The base might contain thin beds or laminae of coarse sand, reflecting alternating conditions of running water and wind deposition that are characteristic of many fluvial environments that developed into aeolian sedimentation systems (e.g., Kasse, 


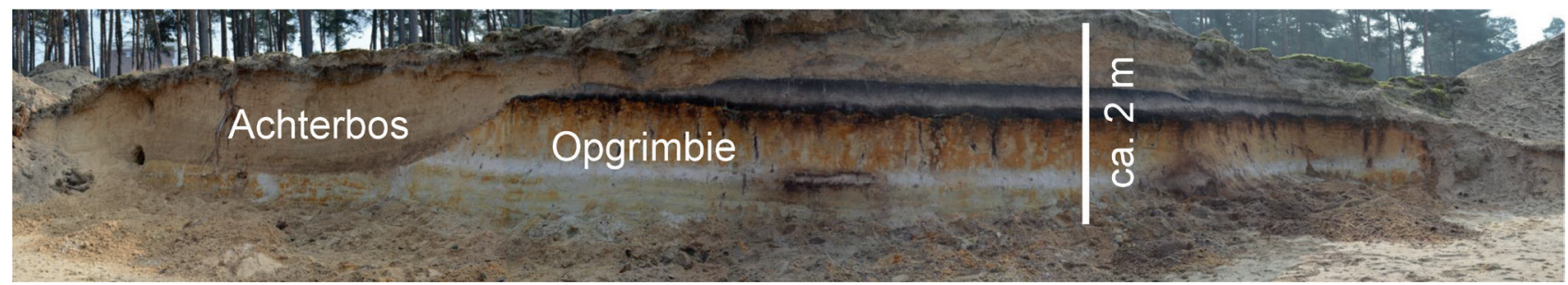

Figure 4. The Achterbos Member at its type locality, where it covers a deflated Podzol that developed in the Opgrimbie Member (height of the profile is ca. $2 \mathrm{~m}$; Photograph B. Rogiers).

1999; Kasse et al., 2007). Although this classification scheme is very useful in understanding the detailed geological history and landscape evolution of the region, it is not very practical for mapping purposes (Schokker et al., 2007). The Opgrimbie Member is not further subdivided into beds.

\subsection{Achterbos Member}

The Achterbos Member consists of (dull) greyish-yellow very well-sorted and loosely packed fine sand (mode between $125-250 \mu \mathrm{m}$ ) sometimes displaying $\mathrm{cm}$ to $\mathrm{dm}$-scale bedding caused by subtle variations in grain-size (Table 3; Fig. 4). Stratification, if present, can be oblique or parallel. Individual sub-layers may contain up to $10 \%$ coarse sand $(>0.5 \mathrm{~mm})$ and/or up to $10 \%$ silt and clay $(<63 \mu \mathrm{m})$. The origin of these sands can be traced back to deflated Podzols and the (aeolian) parent material these were formed in. The lower boundary of the unit is very clear if it overlays older (aeolian) fine sandy deposits with soil development but less clear if the soil had been removed by aeolian deflation. In sedimentary sequences the unit is always laying on top; often an incipient soil can be observed in the top of this unit. Deposits from the Achterbos Member can be found throughout the Belgian sand belt.

Typically, this member may be very thin but can reach thicknesses of up to a few metres. The stratotype is located on the interfluve between the Kleine Nete and the Breiloop (Kleine Nete catchment; N51²'57”, E5 ${ }^{\circ} 05^{\prime 2} 7^{\prime}$; Fig. 1), where these sands typically lay on top of (partially) eroded Podzol soils (Fig. 4).

According to pedostratigraphical criteria, deposits from the Achterbos Member postdate the formation of Podzols in the Belgian sand belt; consequently they are Holocene in age (Table 4). Recent optically stimulated luminescence dating results indicate that the majority of the sediments was deposited during the last three millennia (e.g. Derese et al., 2010a; Beerten et al., 2012; 2014; Beerten \& Grade, 2016).

The Achterbos Member is newly introduced to replace the Kalmthout Member (ranked as a formation by the De
Ploey (1961)) as defined in Gullentops et al. (2001) in order to avoid confusion with respect to the source material of this member (i.e. 'reworked sands from the Hechtel Formation', see Gullentops et al., 2001). Indeed the Achterbos Member may also contain reworked sands from other formations. In this way, confusion with respect to the morphological connotation is avoided as well, given that these drift sands do not necessarily produce a dune landscape. The Achterbos Member can be correlated with the Kootwijk Member in the Netherlands (Table 2).

\subsection{De Panne Member}

The De Panne Member consists of yellow-grey to grey fine to medium fine sand, exceptionally medium sand, with peaty layers or humus-rich surfaces and pale yellow to grey sand with shell fragments (Table 3 ). The stratification is characterised by cross-bedding with varying dipping angles (Lebbe \& De Ceunynick, 1980; De Ceunynck, 1984; 1985; Baeteman, 2001) (Fig. 5). The sand deposits may be several metres thick and occasionally this stratigraphical unit reaches up to 7 metres or more. The De Panne area is considered to be the stratotype area for the coastal dunes deposits (superficial and buried), because they are well-developed there (Fig. 1).

A precise stratotype location still needs to be defined.

Deposits from this member can be found all along the Belgian coastline and in some part of the coastal plain, mostly as isolated parts. The latter are known as the inland dunes. According to Baeteman (2004) the inland dunes developed progressively from the west to the east in several steps and during several time periods, at least around ca. 4.5 $\mathrm{ka}$. In the stratotype area the dune development can be traced from $2.8 \mathrm{ka}$ onwards, with several interruptions (Lebbe and De Ceunynck, 1980; De Ceunynck, 1985). The two youngest phases are situated respectively prior the $14^{\text {th }}$ century $\mathrm{AD}$ and during the $14^{\text {th }}$ and $15^{\text {th }}$ century AD (Table 4 ).

The De Panne Member was introduced by Depuydt (1972) and classified as part of the marine and estuarine Vlaanderen

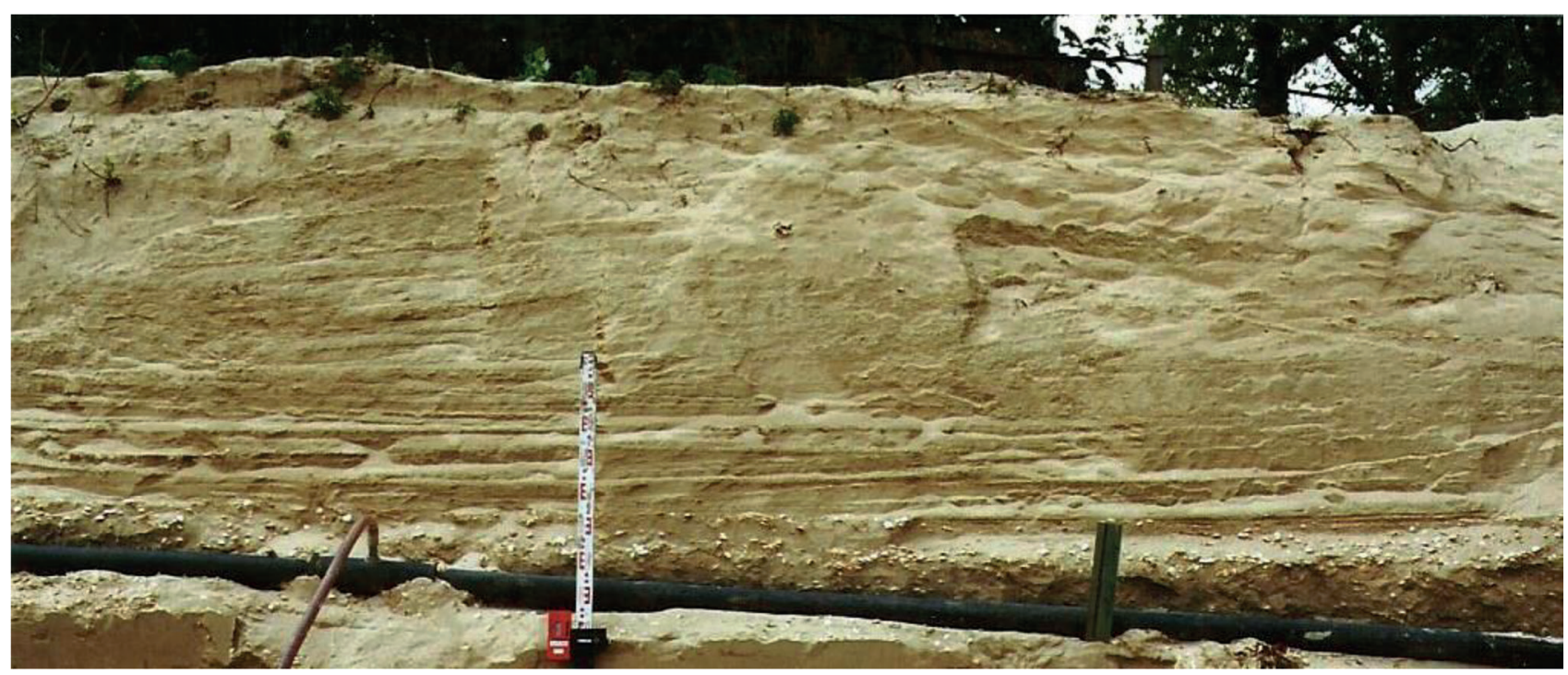

Figure 5. The De Panne Member in Nieuwpoort (Photograph C. Baeteman). 
Formation by Gullentops et al. (2001). The same practice was followed in the Netherlands, where coastal dunes are part of the Naaldwijk Formation (Schoorl Member; Weerts, 2003; see Table 2). As the member consists of aeolian sands, however, it is more appropriate to include it in the Gent Formation.

\section{Discussion}

The presented lithostratigraphical criteria for the Gent Formation allow both ranking the Quaternary winddominated sandy deposits in Belgium and distinguishing them from formations with comparable lithologies. The dominant lithology is fine sand, with small amounts of silt in the matrix or in thin beds or laminae. It usually has a homogeneous appearance while palaeosoils, cryoturbations and frost cracks might be readily visible in cross-sections. One or several combinations of these criteria allow to identify deposits from the Gent Formation. Although the homogeneous slightly silty fine sand shows dynamic/variable environmental conditions, the available data clearly point to an aeolian origin for this formation. The sands all belong to formations and members that in older stratigraphical schemes were grouped under genetic terms such as coversand, dune sand and drift sand. The development of the Gent Formation can thus be seen in the light of specific palaeoenvironmental conditions. In general, there is a strong causal relationship between the absence of vegetation and the effectiveness of aeolian processes (Hoek, 2001; Kasse et al., 2007; Küster et al., 2014). As such, the Gent Formation principally includes all sediments that were deposited under conditions of decreased landscape stability, as a result of a reduced vegetation cover. Reduction in vegetation cover can be climatically controlled (dry and/or cold conditions), related to sea-level fluctuations (destruction of vegetation due to sea level rise or lowering and supply of abundant source material (marine and terrestrial)) and/or the result of human activities (land use changes).

Expert knowledge might be needed to distinguish different members within the Gent Formation. The Dilsen Member can be identified with the following combination of criteria: grainsize, post-depositional processes (Bt horizon of interglacial soil) and stratigraphical relationships (always covered by younger deposits). The Tisselt Member and Opgrimbie Member have some diagnostic properties in common, but they differ on one main point that is crucial in their identification: the latter has a homogenous appearance, while the former is clearly a composite deposit. Whereas in general the amount of silt in the size fractions increases from north to south for both members (Fig. 1), the sedimentological difference clearly points to contrasting palaeoenvironments. The Opgrimbie Member has been deposited under dry conditions, while the Tisselt Member has been deposited under conditions when wet episodes were still common. Wet circumstances may vary from damped conditions where sedimentation results in adhesion structures to conditions of local running water reworking previously deposited material.

In geological cross-sections, the Tisselt Member is always covered by the Opgrimbie Member, suggesting that the former is the oldest unit of the two. However, in the absence of detailed age control for this member, it cannot be ruled out that the Tisselt and Opgrimbie members are partly lateral equivalents. In depressions and valleys, aeolian sedimentation under wet conditions might continue much longer than on adjacent interfluves, even under the same climate. For the greater part, the Dilsen, Tisselt and Opgrimbie members have been deposited under periglacial conditions.

The present lithostratigraphical scheme for the Gent Formation does not make use of pebble layers, such as the Beuningen Gravel, or the presence of periglacial deformation phenomena, to further subdivide the Opgrimbie Member. The Opgrimbie Member is intended to group the slightly silty, and dominantly sandy surficial wind-dominated deposits, and differs in this respect from the Tisselt Member, where discrete silt layers are abundant. This is a pure lithological criterion that can be used to encode borehole descriptions. Instead, a thin pebble layer and/or periglacial deformation phenomena are easily overlooked in coring surveys. This lithological criterion makes the Opgrimbie and Tisselt Members entirely mappable. Furthermore, there are several levels of cryoturbations and pebble layers in the Weichselian (Vandenberghe, 1985), such that these would not be very practical to use as a criterion. Another issue might be the interpretation of the term 'periglacial deformation phenomena'. Frost fissures, that do occur above the Beuningen Gravel, are often difficult to discriminate from ice-wedge casts or sand wedges.

The De Panne and Achterbos Members are Holocene in age and point to different palaeoenvironmental conditions than the other three members. They were both deposited under temperate conditions. Most importantly, the Achterbos Member is partly the result of human-environment interactions (land use change), while the De Panne Member clearly is the result of marine-terrestrial interactions.

\section{Conclusion}

The new lithostratigraphical scheme for the Quaternary sandy wind-dominated deposits in Belgium should allow field geologists to identify the Gent Formation and distinguish different members based purely on lithological and associated macroscopic features such as soil horizons or interbedded gravel pavements. In general, the fine sand deposits described here feature a specific range of grain size classes, from almost pure sand (Achterbos Member) to sandy silt (Tisselt Member). In addition, they are usually well-sorted. Further diagnostic criteria are the presence of periglacial deformation phenomena (cryoturbations, ice-wedge casts), soil horizons and/or cultural layers in the Opgrimbie Member, alternating sand and silt layers in the Tisselt Member, the typical pedostratigraphical position of the Achterbos Member, and the pale yellow to greyish colour and presence of shell remains in the De Panne Member.

\section{Acknowledgments}

This manuscript is a result of working-group meetings of the National Stratigraphic Commission Belgium, Subcommission Quaternary. Jan Walstra is thanked for producing Figure 1. DV gratefully acknowledges financial support from the Research Foundation - Flanders (FWO). The authors would like to thank the reviewers whose comments and suggestions helped improving the manuscript.

\section{References}

Baeteman, C., 2001. De Moeren and Inland Dunes - Holocene depositional history: Excursion Guide Field meeting Geologica Belgica, June 2001. Geologica Belgica, Brussels, 41 p.

Baeteman, C., 2004. The Holocene development of a tide-dominated coastal lowland. Western coastal plain of Belgium. Field Guide. The QRA Third International Postgraduate Symposium Fieldtrip, September $17^{\text {th }}$ 2004. Belgian Geological Survey, Brussels, 76 p.

Beerten, K., Deforce, K. \& Mallants, D., 2012. Landscape evolution and changes in soil hydraulic properties at the decadal, centennial and millennial scale: A case study from the Campine area, northern Belgium. CATENA, 95, 73-84.

Beerten, K., Vandersmissen, N., Deforce, K. \& Vandenberghe, N., 2014. Late Quaternary (15 ka to present) development of a sandy landscape in the Mol area, Campine region, NE Belgium. Journal of Quaternary Science, 29, 433-444.

Beerten, K. \& Grade, A., 2016. Optically stimulated luminescence dating of sand samples from the Molenakkers, Retie (B). Restricted Contract Report SCK $•$ CEN R-6219. Mol, Belgium, 15 p.

Bogemans, F., 1988. Thematische kwartairgeologische voorstellingen als toepassings-modellen in de economische ontwikkeling. Unpublished $\mathrm{PhD}$ thesis. Vrije Universiteit Brussel, $208 \mathrm{p}$.

Bogemans, F., 1993. Quaternary geological mapping on basis of sedimentary properties in the eastern branch of the Flemish Valley. Toelichtende Verhandelingen voor de Geologische en Mijnkaarten van België, 35, 1-49.

Bogemans, F. \& Vandenberghe, D., 2011. OSL dating of an inland dune along the lower River Scheldt near Aard (East Flanders, Belgium). Netherlands Journal of Geosciences, 90, 23-29. 
Busschers, F.S., Kasse, C., van Balen, R.T., Vandenberghe, J., Cohen, K.M., Weerts, H.J.T., Wallinga, J., Johns, C., Cleveringa, P. \& Bunnik, F.P.M., 2007. Late Pleistocene evolution of the RhineMeuse system in the southern North Sea basin: imprints of climate change, sea-level oscillation and glacio-isostacy. Quaternary Science Reviews, 26, 3216-3248.

Buylaert, J.-P., Ghysels, G., Murray, A.S., Thomsen, K.J., Vandenberghe, D., De Corte, F., Heyse, I. \& Van den haute, P., 2009. Optical dating of relict sand wedges and composite-wedge pseudomorphs in Flanders, Belgium. Boreas, 38, 160-175.

De Ceunynck, R., 1984. A contribution to the study of dune deposits of the Belgian coastal plain. Bulletin van de Belgische vereniging voor Geologie, 93, 251-254.

De Ceunynck, R., 1985. The evolution of the coastal dunes in the Western Belgian coastal plain. Eiszeitalter und Gegenwart, 35, 33-41.

De Ploey, J., 1961. Morfologie en Kwartair-stratigrafie van de Antwerpse Noorderkempen. Acta Geographica Lovaniensia, 1, 1-130.

Depuydt, F., 1972. De Belgische strand- en duinformaties in het kader van de geomorfolgie der zuidoostelijke Noordzeekust. Verhandelingen van de Koninklijke Vlaamse Academie voor Wetenschappen, Letteren en Schone Kunsten van België, Klasse der Wetenschappen, 122, 1-228.

Derese, C., Vandenberghe, D., Paulissen, E. \& Van den haute, P., 2009. Revisiting a type locality for Late Glacial aeolian sand deposition in NW Europe: Optical dating of the dune complex at Opgrimbie (NE Belgium). Geomorphology, 109, 27-35.

Derese, C., Vandenberghe, D., Eggermont, N., Bastiaens, J., Annaert, R. \& Van den haute, P. 2010a. A medieval settlement caught in the sand: Optical dating of sand-drifting at Pulle (N Belgium). Quaternary Geochronology, 5, 336-341.

Derese, C., Vandenberghe, D.A.G., Zwertvaegher, A., Court-Picon, M., Crombé, P., Verniers, J. \& Van den haute, P., 2010b. The timing of aeolian events near archaeological settlements around Heidebos (Moervaart area, Belgium). Netherlands Journal of Geosciences, 9, 173-186.

Derese, C., Vandenberghe, D.A.G., Van Gils, M., Mees, F., Paulissen, E. \& Van den haute, P., 2012. Final Palaeolithic settlements of the Campine region (NE Belgium) in their environmental context: Optical age constraints. Quaternary International, 251, 7-21.

Doppert, J.W.Chr., Ruegg, G.H.J., van Staalduinen, C.J., Zagwijn, W.H. \& Zandstra, J.G., 1975. Formaties van het Kwartair en BovenTertiair in Nederland. In: Zagwijn, W.H. \& van Staalduinen C.J. (eds), Toelichting bij geologische overzichtskaarten van Nederland. Rijks Geologische Dienst, Haarlem, 11-56.

Gullentops, F., 1957. Quelques phénomènes géomorphologiques depuis le Pléni-Wurm. Bulletin de la Société belge de Géologie, de Paléontologie et d'Hydrologie, 66, 86-95.

Gullentops, F., Paulissen, E. \& Vandenberghe, J. 1981. Fossil periglacial phenomena in NE Belgium (excursions in the Kempen on 26 and 27 September 1978). Biuletyn Peryglacjalny, 28, 345-365.

Gullentops, F., Bogemans, F., De Moor, G., Paulissen, E. \& Pissart, A., 2001. Quaternary lithostratigrafic units (Belgium). Geologica Belgica, 4, 153-164.

Haesaerts, P., Pirson, S. \& Meijs, E., 2011. Romont Group. National Commission for Stratigraphy Belgium. Retrieved 2015-02-13 from $\mathrm{http}: / /$ ncs.naturalsciences.be/quaternary/41-romont-group-0.

Hoek, W.Z., 2001. Vegetation response to the $\sim 14.7$ and $\sim 11.5 \mathrm{ka}$ cal. BP climate transitions: is vegetation lagging climate? Global and Planetary Change, 30, 103-115.

International Commission on Stratigraphy, 2015. Stratigraphic guide: lithostratigraphic units. Retrieved 2015-11-04 from http://www. stratigraphy.org/upload/bak/litho.htm.

Kasse, C., 1999. Late Pleniglacial and Late Glacial aeolian phases in The Netherlands. GeoArchaeoRhein, 3, 61-82.

Kasse, C., Vandenberghe, D., De Corte, F. \& Van den haute, P., 2007. Late Weichselian fluvio-aeolian sands and coversands of the type locality Grubbenvorst (southern Netherlands): sedimentary environments, climate record and age. Journal of Quaternary Science, 22, 695-708.

Küster, M., Fülling, A., Kaiser, K. \& Ulrich, J., 2014. Aeolian sands and buried soils in the Mecklenburg Lake District, NE Germany: Holocene land-use history and pedo-geomorphic response. Geomorphology, 211, 64-76.

Lebbe, L. \& De Ceunynck, R., 1980. Lithostratigrafie van het duingebied ten westen van De Panne. Aardkundige Dienst van België, Professional Paper, 171, 1-32.

Martinson, D.G., Pisias, N.G., Hays, J.D., Imbrie, J.D., Moore, T.C. \& Shackleton, N.J., 1987. Age dating and the orbital theory of the ice ages: development of a high-resolution 0 to 300,000-year chronostratigraphy. Quaternary Research, 27, 1-29.

Paepe, R. \& Vanhoorne, R., 1967. The stratigraphy and palaeobotany of the Late Pleistocene in Belgium. Toelichtende Verhandelingen voor de Geologische en Mijnkaarten van België, 8, 1-96.

Paepe, R. \& Vanhoorne, R., 1976. The Quaternary of Belgium in its relationship to the stratigraphic legend of the geological map. Toelichtende Verhandelingen voor de Geologische en Mijnkaarten van België, 18, 1-38.
Paulissen, E., 1973. De morfologie en de kwartairstratigrafie van de Maasvallei in Belgisch Limburg. Verhandelingen van de Koninklijke Vlaamse Academie voor Wetenschappen, Letteren en Schone kunsten van België, Klasse der Wetenschappen, 127, 1-266.

Paulissen, E. \& Munaut, A.V., 1969. Un horizon blanchâtre d'âge Bölling à Opgrimbie. Acta Geographica Lovaniensia, 7, 65-91.

Schokker, J., de Lang, F.D. , Weerts, H.J.T., den Otter, C. \& Passchier, S., 2005. Formatie van Boxtel. In: Lithostratigrafische Nomenclator van de Ondiepe Ondergrond. Retrieved 2015-02-13 from https://www. dinoloket.nl/nomenclator-ondiep.

Schokker, J., Weerts, H.J.T., Westerhoff, W.E., Berendsen, H.J.A., den Otter, C., 2007. Introduction of the Boxtel Formation and implications for the Quaternary lithostratigraphy of the Netherlands. Netherlands Journal of Geosciences, 86, 197-210.

TNO, 2013. Lithostratigrafische Nomenclator van de Ondiepe Ondergrond, versie 2013. Retrieved 2015-02-13 from https://www. dinoloket.nl/nomenclator-ondiep.

Vandenberghe, J., 1985. Paleoenvironment and stratigraphy during the Last Glacial in the Belgian-Dutch border region. Quaternary Research, 24, 23-38.

Vandenberghe, J. \& Gullentops, F., 1977. Contribution to the stratigraphy of the Weichsel Pleniglacial in the Belgian coversand area. Geologie en Mijnbouw, 56, 123-128.

Vandenberghe, D., Vanneste, K., Verbeeck, K., Paulissen, E., Buylaert, J.-P., De Corte, F. \& Van den haute, P., 2009. Late Weichselian and Holocene earthquake events along the Geleen fault in NE Belgium: OSL age constraints. Quaternary International, 199, 56-74.

Van der Hammen, T., 1951. Late glacial flora and periglacial phenomena in the Netherlands. Leidse Geologische Mededelingen, 17, 71-183.

Van der Hammen, T. \& Wijmstra, T.A., 1971. The Upper Quaternary of the Dinkel valley (Twente, Eastern Overijssel, The Netherlands). Mededelingen Rijks Geologische Dienst, 22, 55-212.

Van Nieuland, J., Vandenberghe, D., Gelaude, F. \& Van den haute, P., 2013a. Absolute dating of aeolian sediments in relationship to the development of the city of Ghent: first results. Mediterranean Archaeology and Archaeometry, 13, 25-35.

Van Nieuland, J., Vandenberghe, D., Buylaert, J.-P., Paulissen, E. \& Van den haute, P., 2013b. Optical dating of inland dunes in the Campine area (NE Belgium): a case study. Book of abstracts $11^{\text {th }}$ International Conference "Methods of Absolute chronology", 15-18 th $^{\text {th }}$ My 2013, Podlesice, Poland, p. 41.

Weerts, H.J.T., 2003. Formatie van Naaldwijk. Lithostratigrafische Nomenclator van de Ondiepe Ondergrond. Retrieved 2015-02-13 from https://www.dinoloket.nl/formatie-van-naaldwijk.

Manuscript received 18.11.2015, accepted in revised form 07.04.2017, available on line 17.06.2017. 